\title{
Constructing Chains of Enablers for Alternative Economic Futures \\ Denmark as an Example
}

Hull Kristensen, Peer

Document Version

Final published version

Published in:

Academy of Management Perspectives

DOI:

10.5465/amp.2015.0152

Publication date:

2016

License

Unspecified

Citation for published version (APA):

Hull Kristensen, P. (2016). Constructing Chains of Enablers for Alternative Economic Futures: Denmark as an Example. Academy of Management Perspectives, 30(2), 153-166. https://doi.org/10.5465/amp.2015.0152

Link to publication in CBS Research Portal

\section{General rights}

Copyright and moral rights for the publications made accessible in the public portal are retained by the authors and/or other copyright owners and it is a condition of accessing publications that users recognise and abide by the legal requirements associated with these rights.

\section{Take down policy}

If you believe that this document breaches copyright please contact us (research.lib@cbs.dk) providing details, and we will remove access to the work immediately and investigate your claim. 


\title{
Constructing Chains of Enablers for Alternative Economic Futures: Denmark as an Example
}

\section{Peer Hull Kristensen}

\author{
Journal article (Final published version)
}

CITE: Constructing Chains of Enablers for Alternative Economic Futures : Denmark as an Example. / Hull Kristensen, Peer. In: The Academy of Management Perspectives, Vol. 30, No. 2, 05.2016, p. $153-166$.

DOI: 10.5465/amp.2015.0152

Uploaded to Research@CBS: January २०18 


\title{
$\begin{array}{lllllllll}S & \mathrm{Y} & \mathrm{M} & \mathrm{P} & \mathrm{O} & \mathrm{S} & \mathrm{I} & \mathrm{U} & \mathrm{M}\end{array}$
}

\section{CONSTRUCTING CHAINS OF ENABLERS FOR ALTERNATIVE ECONOMIC FUTURES: DENMARK AS AN EXAMPLE}

\author{
PEER HULL KRISTENSEN \\ Copenhagen Business School
}

\begin{abstract}
Though capitalism may be structured in divergent ways that produce highly different outcomes, and though the capitalist process needs new demands and technologies to realize its expansionary potential, these lessons seem to have been ignored in recent discussions of how to revitalize mature economies. This article illustrates a way of researching alternative economic futures by identifying chains of enablers in Denmark and other Nordic countries by which society and business can co-develop and capture capabilities to take on new roles in globalization. The paper focuses on institutional enablers that have made possible novel forms of work organization and business models. These institutional enablers are capacitating on the "supply side" by enabling labor to take an active part in shaping enterprises supported by social welfare services (training, childcare and eldercare, support for housing, etc.). Being generally inclusive of social movements, welfare states have also helped identify new needs on the "demand side" such as toys, aids, technologies, and buildings for childcare and eldercare, environmental protection, alternative energy and energy saving, health, and city planning. This is illustrated by a number of firms that supply products that solve societal problems, and that have used their capabilities to become multinationals that engage in active co-development with firms and institutions in foreign countries.
\end{abstract}

During the last two decades of the 20th century, when different schools of economic sociology and political economy came to see capitalism as composed of countries with divergent institutions that constituted divergent forms of firms, finance, and labor markets effecting different pathways for economic progress (Hall \& Soskice, 2001; Maurice et al., 1986; Whitley, 1999; for an overview, see Morgan \& Kristensen, 2014), the dominant pattern of capitalism changed. From a general accumulation regime in which mass production was seen by economists to be complemented by Keynesian

I am grateful to Paul S. Adler and Gerald F. Davis for bringing this symposium together and to AMP co-editorin-chief Don Siegel and anonymous reviewers for advice on the development of this article. Without many years of collaboration with Charles F. Sabel, Gary Herrigel, Kari Lilja, Glenn Morgan, Jonathan Zeitlin, and Richard Whitley my research would be less comprehensive, and without great fieldwork from former students Robson Sø Rocha, Maja Lotz, Julia Kirch Kirkegaard, and Verena C. Girschik it would be based on much less empirical material. demand management and regulation (Aglietta, 1979), economic doctrines changed in favor of state deregulation, market regulation, and competition-in short, neo-liberalism. Earlier visions that had understood that the market and capitalism needed to be shown new frontiers of space, technology, demand, and regulation to expand in a progressive way seemed to have been lost in favor of an expectation that markets and competition would lead to a much more dynamic form of capitalism.

Today it is becoming clear that one of the pivotal effects of this change in political economic doctrines was to bring the financial markets into a dominant position that would change corporate governance, put a premium on shareholder value, and force corporations to focus on short-term financial performance rather than on building complex organizations with multiple commitments to a wide variety of stakeholders (Kelly, 2003; Lazonick \& O’Sullivan, 2000; Mayer, 2013). The fact that this change happened simultaneously with greater access to a multiplicity of low-wage countries via globalization triggered a fundamental change in the architecture of capitalism. 
We clearly see the start of this change in the mid1980s, when large corporations, whether functionally integrated mass producers in command of entire value chains or multidivisional firms able to balance earnings and be fairly independent on external finances, were forced to break up, undermining a multiplicity of corporate communities that had previously constituted the core of broader economic development in the United States (Davis, 2009) and many other mature economies. Instead, production began to disintegrate as large corporations outsourced and/or offshored production and formed global value chains. A more dynamic form of competition developed, in which corporations felt forced to reduce costs to finance innovation by exploiting cheap labor and making continuous improvements in terms of quality, reduced production costs, speed of R\&D, and logistics (Herrigel, 2010). More volatile markets and frequently shifting booms and busts emerged, as the mechanisms that once stabilized demand and supply were abandoned in favor of passing economic risks on to suppliers in distant emerging economies. And these suppliers mutually competed to drive down margins by creating surplus capacities and engaging low-paid, low-skilled, temporary migrant workers (Locke, 2013).

These causes merged with their consequences to create cumulative circles of causation: Corporations now had the best of all possible ways to pressure subsidiaries and suppliers during concessionbargaining in a drive to cut costs, leading to pressures on wages and the emergence of the working poor (Mueller, 1996; Mueller \& Purcell, 1992). This pressure extended to states in the form of pressure to reduce taxes and social services, adding further to inequality and reducing the possibility of balancing supply and demand. There were frequent shifts among prosperous and failing regions, where temporary models of success quickly turned into failures (think of Ireland or Finland) or the other way around (Scandinavian countries and Germany).

It seemed as if countries with highly divergent institutional legacies and distinct complementarities in their respective growth and development regimes were chasing globalization rather than working to carve out a new role for themselves in the new global economic order. This became evident, in particular, during and after the 2007-2008 financial crisis, which made it clear that financial institutions governed both states and corporations, forcing states to reduce public spending and corporations to put pressure on real wages. The successful re-forming of capitalisms seemed to become a question of how quickly a country could adapt to the ideology of neoliberalism by imposing financialization, wage restraints, and austerity. Germany is a good case in point, as it simultaneously exhausted many of the institutions that had previously constituted its coordinated market economy (Streeck, 2009).

On the other hand, as has been carefully and thoroughly researched by Locke (2013), most initiatives to civilize this dominant economic pattern by promoting wage and labor standards in emerging economies have been of only limited success. Private governance seems to have quite tight limits (Mayer \& Gereffi, 2010). There are a few examples of collaboration on continuous improvement among original equipment manufacturers (OEMs) and suppliers. This collaboration has led to partial progress, and where new institutions have been created in favor of monitoring labor rights, gradual progress seems to be possible. On the whole, the global system seems to be self-limiting in this respect, as the suppliers in emerging economies are hiring temporary, lowskilled, migrant workers in highly Taylorized forms of work organization to adapt to the highly shifting levels of demands from their OEM customers, while competition among these suppliers is so intense that their margins-and with them room to improve working conditions and their business modelshave become unbelievably narrow. High profits go to the OEMs when they make use of cheap suppliers, and when their subsidiaries hire workers in emerging economies, they recruit the best skilled. Thus while MNCs are destroying the potential for development in emerging economies, they simultaneously are limiting demand in mature economies by relocating jobs (Locke, 2013, see Chapter 6, especially Table 6.1). Thus, the current accumulation regime blocks the possibility of more broad forms of economic development in both emerging and mature economies. In other words, the current economic system seems to systematically disenable workers throughout the world, reducing entrepreneurial vitality in emerging economies while empowering and enriching corporate managers, financial institutions, and shareholders in mature economies.

\section{EMERGING, MORE PROMISING FORMS OF MNCs COMING OUT OF AND POSSIBLY RESHAPING THE DOMINANT ECONOMIC REGIME}

Despite the trends outlined above, changes are occurring. In particular, a number of latecomers or emergent economies, including Spain, China, South 
Korea, India, Taiwan, Brazil, Russia, and Mexico, have generated numerous and fast-growing multinationals. Many of these companies operate within traditional fields such as foods and beverages, mining, and raw materials, but some are also placed in such knowledge-intensive industries as aircraft, electronics, and IT services. They frequently operate very differently than MNCs of the dominant pattern mentioned above, as they integrate into corporate structures with an international reach in what used to be fragmented industries.

Many of these firms are being institutionally enabled to swim against the stream by their access to financial resources from either state-owned banks or personal networks, often including familyowned corporations, in which the family is highly connected to national elites (Guillén, 2005; Guillén \& García-Canal, 2010, 2013). Often these corporations grow by trading large quantities of goods in less advanced market segments while using some of their revenue to acquire technologically more advanced firms from mature countries, thereby connecting to industrial and technological environments from which they can learn. An illustrative example is that of Chinese and Indian wind turbine producers acquiring subsidiaries in Denmark to acquire knowledge about how to make controllers that make it possible to optimize energy output from windmills and farms, and to gain an understanding of the dynamic exchange with grids (Kirkegaard, 2015).

Although MNCs from emerging economies can, in this way, compensate for a lack of technological competencies by constructing ties to economies that are abundant in such competencies, many supply firms from mature economies, delivering sophisticated parts or subsystems, have become multinationals by following the offshoring and outsourcing strategies of the automotive industry. They create subsidiaries in new host economies to be close to their industrial customers, making innovative collaboration and adaptation to local market conditions easier and faster and benefiting from access to cheaper engineers and skilled workers. Such a strategy provides corporations with an additional way of turning global value chains into global innovation networks and experimenting with new forms of collaborative learning (Herrigel, 2014; Herrigel et al., 2013). Such MNCs supply parts, modules, and systems that are crucial for the constant upgrading of complex products from both emerging and mature OEMs—as, for instance, when Japanese firms supply vital technological parts to
South Korean Samsung, when Bose supplies hi-fi equipment for German luxury cars, and when Danish control equipment producers supply Chinese wind turbine manufacturers with vital equipment for optimizing performances.

Even more promising, there is another step on this ladder of developing advanced business models that create jobs in mature economies. These models were discovered by a group of researchers searching for explanations for why Nordic countries, against neo-liberal expectations, had performed so well during intensified globalization processes during the 1990s (Kristensen \& Lilja, 2011). While investigating how Nordic firms acquired by multinationals as subsidiaries were fighting to maintain and extend their mandate within the multinational, researchers found a general pattern repeated across numerous cases. These acquired subsidiaries (as subsidiaries generally are) were living with frequent changes in new performance criteria, invented by financial institutions to serve shareholder values and deliberately triggered by headquarters to cause rivalry among subsidiaries. A rivalry with shifting benchmarks will often create shifting pressures that cause subsidiaries to follow divergent strategic paths over time, so that a subsidiary winds up being constituted in a dysfunctional and incoherent way.

Though the studied Nordic case companies had experienced similar shifting and incoherent pressures, they seemed to have navigated through these to develop a new and surprisingly coherent business model. Their core legacy was specialty products for industrial and/or institutional customers, on top of which they would then add services that increased value for their customers and led to continuous exchange with them within the technological area of application. Eventually, they would provide systematic continuous improvements to this technological area, helping customer firms and institutions reduce costs and improve quality. By serving numerous customers from many countries and industries, these firms learned the art of defining best practices, making it possible to use what they learned from the solutions they generated for one customer to improve how they worked with other customers. In addition, they would, through these recursive processes, discover new general technological demands that could be translated into new products and service modules. Operating in this way, they became active learning organizations that could move from less to more demanding customers, eventually winding up in highly advanced global innovation networks. 


\section{The Emergence of Small Multinational Corporations}

Danish companies Unimerco and Radiometer are illustrative examples of such forms of small MNCs (SMNCs) that became acquired by larger MNCs but continued to expand in the said way after the merger. Unimerco produces specialty precision tools and services these tools by providing calibration and maintaining precision for customers. It also serves as an agent for a whole set of producers of standard tools, making it possible to combine these tools with its own specialty solutions in a way that optimizes the use of tools at customer firms. In the case of new development projects at customer firms, Unimerco develops new tool solutions, and as a result it has become a close collaborative partner for numerous firms in a broad range of industries. On top of these services, Unimerco has taken over the entire responsibility for managing tools in customer firms, improving the stabilization of quality levels and enabling radical cost cutting. Starting by serving woodworking firms in its home industrial district, it has moved all the way up to servicing highly advanced suppliers to the aircraft industry.

Radiometer has taken a similar route but in a very different sector. The company, a provider of technologically advanced solutions that simplify and automate all phases of acute care testing, began by developing tools to measure critical functions, such as blood gasses and $\mathrm{pH}$ levels in liquids, but then expanded into developing information and communication systems that made it possible to integrate information flows from its own equipment and that of third-party producers so that it could provide a centralized picture of a patient in an acute care setting. As Radiometer worked on the problem of streamlining information, managers discovered that practices at acute care settings differed in many ways, and that there was a strong need for continuous improvement to systematically increase the survival rate of acute patients. They engaged in a comparative search across customer hospitals in many countries, diagnosed and explained problems, and searched for solutions so that the company could serve such settings with continuous training. But simultaneously, managers also identified a number of less satisfying instruments and equipment, which they focused on improving either by asking suppliers for improvements or by initiating their own R\&D projects to develop new instruments.

These examples are illustrative of a general trend in how Danish and Nordic SMEs have developed new business models after they gradually globalized and became SMNCs, some as independent companies and others as parts of larger MNCs. Reflecting past legacies of industrial development, each country has developed such SMNCs in a variety of branches. For example, many firms in Denmark supply sophisticated equipment and services for windmills, for central heating and electrical grids, for the food and beverage industry, for hospitals, for disabled persons, for eldercare and childcare, and for environmental protection. Norway is particularly good at providing equipment and services for offshore oil industries, while Sweden and Finland have focused on providing foreign firms with equipment and services for optimizing the pulp and paper industry (Kristensen \& Lilja, 2011).

As indicated, when such SMNCs become subsidiaries of larger MNCs, they act in an atypical way. First, they either begin as small MNCs (SMNCs) before they become acquired, or they develop into SMNCs within the framework of the MNC later, simply by following their customers' global engagement or by spreading their products and services to new countries. Their ability to learn by comparing customers across nations provides the foundation for their progress. Second, they depend on their ability to work within a long-term perspective, in which the benefits of engaging with one customer often appear only later when they engage with a new customer. This is at odds with the short-term performance focus of finance-driven MNCs and their frequent shifts in performance criteria.

These forms of SMNCs within larger MNCs have been able to thrive and carve out their own technoeconomic space based on a very distinct form of work organization (Kristensen \& Lilja, 2011), a learning organization that is much more widespread in the Nordic countries (and the Netherlands) than anywhere else (Lorenz \& Valeyre, 2003). Investigating this form of organization in more depth, Kristensen and Lotz (2011) found that it is based on having three types of teams. Operational teams acted very autonomously and were manned by highly skilled workers. However, operational teams are only the building blocks on which a much more comprehensive team community is based. Members from different operational teams are combined and recombined in ad hoc innovative teams to serve a particular customer after that customer's specific problems are diagnosed. The so-called R\&D departments of SMNCs typically had just a few employees who acted as project leaders for innovative ad hoc teams manned with people from the operative 
teams. Parallel to these two forms of teams, continuous improvement teams were constituted across the operational teams. These teams included individuals from operational teams that were responsible for a particular (set of) performance goal(s), so that members of operational teams, in addition to having operational duties, are also responsible for improving a distinct set of performance metrics (e.g., internal or external logistics, quality, occupational health and safety, reduction of stores, team leadership methods, environmental consequences, throughput time, communication with internal teams and external customers, etc.).

Kristensen and Lotz (2011) found that whenever a new performance demand was passed down from financial institutions and headquarters, responsibility would be passed down to distinct members of each operational team and cooperatively monitored by a cross-continuous improvement team. The cross improvement teams served both as a forum in which operative teams competing over performance improvements could reveal their experimental results to each other and as a learning community from which members could find inspiration to try new avenues of improvement in each particular operational team. As a result, the operative teams had their operative routines continuously questioned by what they learned from being engaged in a multiplicity of innovative ad hoc teams and being connected through cross improvement teams to what was being learned in other operational teams.

Taking a theoretical look at these forms of work organization and investigating the ambidextrous roles that employees cultivate therein, it becomes clear that these teams have made it possible, in a highly decentralized way, to introduce revolutionary routines (Helper et al., 2000; Sabel, 1994, 2006) that combine exploitation with exploration. Consequently, organizational ambidexterity has become commonplace (for more about this, see Lotz, 2009). This form of work organization makes it possible to understand how these SMNCs have been able to respond to the performance demands imposed by headquarters while simultaneously pursuing a strategy through which they can cultivate increasingly more sophisticated products and services by collaborating with customers and suppliers.

On closer inspection, such organizational forms raise a number of challenging questions: How is it possible to move people around among the different team combinations without causing problems in the form of remuneration schemes? For instance, if a highly skilled and high-performing individual from an operational team is moved to an ad hoc team, both the individual and his or her operational team may lose performativity and earnings for a while. How is it possible for a firm to populate the workplace so extensively with skilled workers who are constantly prepared to take on new challenges and engage in necessary further training in the first place? How is it possible for workers across the factory to work in team communities with a global reach while also working under shifting pressures, meeting highly demanding deadlines in direct cooperative relationships with customers, and frequently leaving their hometowns to get additional training to set up a new subsidiary or to serve a customer in a foreign country? It is almost impossible to imagine that this kind of work organization can be combined with a normal family life based on blue-collar income levels.

The answer to these questions is that these firms have been able to cultivate such forms of work organization because they have been enabled to do so by a set of institutions that provide firms with comparative advantages in finding ways to cope with globalization that have led to entirely new business models and forms of SMNCs, as we shall see in the next section.

\section{CHAIN OF ENABLERS IN THE DANISH WELFARE STATE}

As indicated above, in southern Europe and some emergent economies, some of the identified enablers for paving alternative business paths to the dominating path summarized in the first section include family ownership of business firms and access to "patient" capital through various forms of networks that include financial institutions, which are frequently controlled by the state and political elites. These enablers provide independence from the normal governance mechanisms of the financial community. But it is uncertain whether creating these new forms of multinationals will serve to upgrade and modernize the business units they unify and engage collectively in the global market, or whether they will consolidate exploitive clientilist relations to smaller producers in their supply chains. More research on these corporations and their relations to stakeholders is needed before it will be possible to determine whether they contain the seeds for a new, alternative form of development and growth.

The Nordic countries may constitute a promising case in this respect. To explain the successful evolution of the Nordic countries before the 2008 crisis, Kristensen and Lilja (2011) studied how firms and 
national institutions interacted in searching for new roles globally, and found to their surprise that firms and institutions interacted to form a mutual chain of supply-side capacitating enablers that may be broadly summarized in the following way: Nordic welfare institutions, by combining access to training institutions and transfer payments, enable workers, including members of marginal groups, to constantly search for new skills, whereby they become included-to a greater extent than in most other countries-in the constant redefinition of job roles and professional identities that takes place in firms operating within global innovation networks (GINs). Welfare services such as childcare, eldercare, and housing support make it possible for workers to engage more fully in highly demanding jobs. This enables firms to decentralize responsibilities to operative levels, making possible new forms of learning organizations in which responsibility, discretion, and control rest in the hands of workers who take part in operation design, planning, continuous improvement, and innovation of new services and products.

A legacy of industrial relations (unions, work councils, convenors, and shop stewards) underpins a culture of negotiating that enables such organizations to shift frequently among states of cost-efficient production (exploitation), continuous improvement and innovation (exploration), and combining and recombining organizational elements to deal with shifting and varying customer demands. Shop stewards and convenors, by acting in close collaboration with top managers in securing flows of horizontal coordination, collaboration, and learning, balance or neutralize the temptation for middle managers to compete with each other to position themselves or their units, which often leads to sub-optimization, bottlenecks, and irresponsibility (Dalton, 1959; Jackall, 1988). This in turn enables firms to survive even under shifting performance criteria and to develop a coherent business model, in which they develop products and services while collaborating closely with customers to make endogenous continuous improvements and foster innovation in customer organizations.

Searching for increasingly sophisticated customers globally enables Nordic firms to become increasingly well integrated and well positioned in GINs. This enables them to create a new, low-cost form of SMNC that takes advantage of the constant pressure to innovate and improve and makes use of welfare institutions and further training institutions to supply advanced services and demand new, more advanced products and services. Thus, in many respects, Nordic countries could be seen as having progressed far toward a new growth and development regime and an alternative economic future in which a broad part of the population becomes part of the so-called "projective city" (Boltanski \& Chiapello, 2007; Kristensen, 2013).

In the Danish case, these sets of enablers are being activated in a dynamic that can be associated with flexicurity (Madsen, 2006). But whereas Danish flexicurity frequently has been associated with a social contract in which employers gain the right to hire and fire easily in exchange for workers being covered by generous unemployment benefits and access to further training, this dynamic actually seems to work in a very different way. Universal rights to welfare services, where access to social benefits is not tied to a particular employer, make workers much more mobile (Morgan, 1997).

Workers are freer to search for new jobs if they become dissatisfied with current employers. Thus, most workers leave a job when they themselves decide to search for a new one (60\% typically do so during high-unemployment periods, $85 \%$ during low-unemployment periods), while very few workers become unemployed as a result of being fired. The proportion of job-hoppers to total employed is very high (between $20 \%$ and $30 \%$ of all those who are economically active), primarily because the majority are searching for new challenges through which they can make use of and cultivate new skills. This horizontal mobility coexists with vertical mobility so that a long-term career may bring even an apprentice to a very high position in a firm or institution (Eriksson et al., 2006; Kristensen, Rocha, \& Lotz, 2011). One unintended effect of this high mobility is that more highly skilled workers deselect poor jobs and firms and concentrate in firms in which challenges and possibilities for skill development and room for advancement exist, making those firms favorable choices for even better jobs in the future. In this way, vanguard firms become endowed with highly skilled workers with high aspirations. The SMNC business models described above constitute a very neat complementarity to this labor market dynamic.

This labor market dynamic, in which male craft and unskilled workers competed constantly for jobs by upgrading skills through competing vocational training institutions and frequent job shifts, until recently only marginally engaged women in the general dynamic. However, the active labor market policies of the 1990s, together with the local experimental search for co-transforming local labor markets 
and work organization, engaged unemployed workers in skill-upgrading and changed the system by diffusing it to nearly all sectors of the economy and groupings of workers, including unskilled women (Kristensen \& Morgan, 2012).

Thus, in the new growth and development regime that was in the making in the 1990s, there was a remarkable symmetry in how the public and private sectors developed. Both were decentralizing responsibilities to operative levels, allowing for much more innovation in supplying more tailored products and services to customers and clients, so that firms and institutions became oriented toward userled innovation and toward solving situational or individualized problems. The reformers hardly noticed this symmetry in organization and strategy because they were much more informed by neoliberalism and new public management, which saw the basic traits as a matter of institutionalizing markets and competition within the public sector. The change came through a multiplicity of organizational changes in firms, through novel ways of working in municipalities (Bogason, 2001), and as a silent switch in state-level reforms (Torfing, 2003).

Though many of the firms based on specialized products, services, and continuous improvement contracts served other private firms (in Denmark, for example, these firms included Unimerco, Foss, Welltec, Grundfos, Danfoss, Novozymes, Haldor Topsøe, Chr.Hansen, Danisco, FLSmith, Universal Robots, and a whole hub of firms delivering components and control systems for wind-turbine producers), many firms were also oriented toward the public-sector market or toward assisting other firms in meeting public regulations (e.g., regulations related to work environment, pollution, energy saving, wastewater treatment, etc.). In other words, the public sector also served as capacitating enablers on the demand side by forming institutional demand or regulations that created a demand for new products and services.

Thus, the Nordic countries have developed a huge concentration of firms that supply the public sector with sophisticated goods and services and operate on the logic sketched out above (famous firms that do so in Denmark include pharmaceutical firms such as Novo Nordisk; hearing aid manufacturers such as Oticon, Widex, and GN-Resound; firms that supply equipment and services to hospitals such as Radiometer, Coloplast, and Systematic; and other firms delivering IT systems to the public sector, as well as a number of firms supplying special equipment to disabled persons). Finally, energy-saving regulations have spurred a high concentration of firms in green industry (examples in Denmark include Grundfos, Danfoss, Haldor Topsøe, Novozymes, Vestas, and Siemens Windpower, and an abundance of smaller firms that make it possible to supply energy from heterogeneous sources) (for an overview of significant Danish-based MNCs, see Nielsen, 2013).

An interesting aspect of these firms is that they engage with customers through products, services, and improvement contracts to increase quality while simultaneously reducing the quantitative demand on resources. Of course, economizing with scarce resources has always been an internal aspect of how capitalist firms achieve profitability, but the systematic coverage and inclusion of what used to be externalities to business enterprises can be seen as a more comprehensive reorientation of the growth and development regime toward providing more quality instead of more quantity—or, in other words, being oriented toward the construction of a more socioeconomically sustainable form of capitalism. But this, of course, depends on how creative the firms are in finding solutions and improvements. This creativity needs to be monitored, either by public demand and government regulations or by entering into GINs that are searching for solutions to environmental and social problems.

Many of the mentioned firms originally evolved through intensive interaction with public or private organizations in Denmark, but very quickly outgrew their home market to become highly export-intensive. But the more their products became "customerized" and connected to tailored services to fit foreign local markets, the more these firms transitioned into an SMNC structure.

\section{POSSIBILITIES FOR CO-DEVELOPMENT ON A GLOBAL SCALE}

As we have seen, numerous firms in the Danish business system have evolved from a chain of institutionalized capacitating enablers, both on the supply and demand side. As we shall see in this section, they engage in foreign markets in such a way that they become part of or even constitute chains of enablers for more sustainable growth in these host economies. As in many European countries, business corporations have implicitly considered institutionalized obligations to other stakeholders or regulations, and now this has become explicit by incorporating performance metrics on corporate social responsibility (Matten \& Moon, 2008). Corporate social responsibility then becomes an assessment 
tool for how to engage in foreign countries, including emerging economies. In much the same way as Selznick (1957) saw how enterprises could institutionalize themselves while becoming active expressions of and participants in the construction of local communities or national economies, firms with these legacies of stakeholder and institutional responsibilities may therefore play a more responsible role in foreign, and particularly developing or emerging, economies.

A similar vision in the United States is being discussed as a way to reinvent capitalism-and unleash a wave of innovation and growth-by Porter and Kramer (2006, 2011). The idea is that corporations should create profit and value not only for themselves, but also for people and the planet. In other words, shared value. As with Kelly's (2003, 2012) concept of the generative enterprise, the idea is to make the corporation aware of how, by contributing to the long-term evolution of the home or host communities in which it operates, it can create better possibilities for economic development (helping foster business clusters), improve living and working conditions, and search for ways to become environmentally sustainable. Both Kelly and Porter and Kramer see the current short-termism and shareholdervalue orientation imposed by the financial community as an obstacle to such a reinvention of capitalism. Kelly's (2012) book is a search for alternative ways to organize ownership.

Some of the most promising effects of MNCs' drive toward shared value have been seen when MNCs address markets at the bottom of the pyramid (BoP) that are closely related to their main businesses and therefore represent new areas in which their current expertise can be used to solve problems on a major scale (Jenkins, 2005; Prahalad, 2004).

Danish company Grundfos, a world leader in the design and manufacture of pumps, is an example. Grundfos is heavily engaged in numerous aspects of CSR and has recently changed its focus to develop more broadly scoped businesses in, for instance, water management for sustainable development. One initiative in this direction is Lifelink, which aspires to provide rural communities in Africa, Asia, and Latin America with drinking water at affordable prices. To accomplish this, it has developed a turnkey solution with a pump, renewable energy production, a water dispenser, and mobile payment, set up in partnership with local governments and development organizations. Between 2009 and 2013, 40 projects covering 100,000 people were set up, but the potential need is estimated to be much, much higher.
Such cases are not restricted to Nordic corporations, however. For instance, Andre (2014) studied a number of French cases, some of which are highly illustrative of how such an approach to business growth and cultivation of shared value in emerging and developing countries can be encouraged. Danone, a French global company in the food and beverage industry, has cultivated a strategy of bringing enriched dairy products and bottled water to low-income areas in Bangladesh, Cambodia, China, France, India, Indonesia, Mexico, and Senegal through dedicated distribution channels and by supporting social businesses financially and technically within these business areas. Electricité de France (EDF) is a French electricity utility leader in Europe, engaged in energy generation, transmission, distribution, supply, and trading, which since 1999 has decided "to proactively fight fuel poverty and promote access to electricity" ${ }^{\text {"1 }}$ as part of its CSR policy. EDF has initiated projects in Botswana, Laos, Mali, Morocco, Senegal, and South Africa. By creating decentralized service companies and employing local managers and personnel, EDF helps with funding, attracting financial resources from local companies, utilities, multinationals, banks, and development agencies. Essilor, a leading French ophthalmic optics company that designs, manufactures, and markets lenses, launched an initiative (as part of its CSR) to "improve lives by improving sight," 2 focusing on the 2.5 billion people who have no access to visual correction. Lafarge, a worldwide leader in building materials, has engaged with a number of NGOs to support housing projects for underprivileged groups by providing building materials, skills support, and assistance in setting up sources of microfinances and working in programs with real estate developers.

These BoP projects have obvious advantages for the BoP populations, but they also simultaneously offer the initiating MNCs new opportunities for codevelopment in the form of opportunities for financial gain, strategic business improvement, positive public relations, development of employee competencies, innovation spreading, and organizational restructuring (Andre, 2014; Keating \& Schmidt, 2008). However, as with anything else in multinationals, such efforts are very dependent on attitudes at MNC headquarters, which can be highly volatile

\footnotetext{
${ }^{1}$ See https://www.edf.fr/sites/default/files/Responsable\% 20engage/edf_group_csr_commitments_2015_results.pdf.

${ }^{2}$ See http://www.essilor.com/en/Group/Sustainable/ Pages/Societal.aspx.
} 
and dependent on shifting management fashions, changes in executive positions, and organizational restructuring (Dörrenbächer \& Geppert, 2011; Kristensen \& Zeitlin, 2004). A good example of this is when Hewlett-Packard closed down its BoP program that had been designed to empower populations with access to ICT (Andre, 2014). Typically, MNCs may be bad at diagnosing problems and finding solutions in the first place, and if they fail in first attempts instead of engaging in learning processes, internal critics may undermine visionary advocates. Part of the problem with MNCs developing more robust programs is the lack of appropriate metrics that can be used to measure and correct the dynamic that is subsequently set in motion, in terms of both its social impact and its potential to prove a sound, profitable business case in the longer run. Only when a sustainable business case can be demonstrated will it be possible to create a financially robust, cumulative, and long-term dynamic that does not stand and fall by the grace of good- or bad-willed top managers.

But to co-produce beneficial societal effects and a sound business model does not depend only on the MNC and the BoP market. As mentioned in nearly all of Andre's (2014) cases, the MNC operates together with sets of local agents that are often complicated (village entrepreneurs, financial institutions, NGOs, other multinationals, government bodies, and public institutions). Relationships among these agents are contingent on many contextual influences, and there is no secure route to making them continuous and robust. Their evolution is especially highly connected with the building up of technical, social, entrepreneurial, financial, and institutional skills that may suddenly change the general positioning of local agents in the role matrix and hierarchy of developing countries, which lack people with practical skills in many fields. This makes it difficult to settle and stabilize a given field, as challengers frequently undermine the positions of incumbents (Fligstein \& McAdam, 2012).

Actually, in many cases it might be necessary for multinationals to change the field before a BoP market is established. A good example of this is the complicated route that the Danish MNC Danfoss, in association with the engineering consultancy firm Cowi, had to take before it could sign a heating system contract in 2013 for the Anshan district in China, for which it won the Greentech Award in 2014 (International District Energy Association, 2014). The project will supply 1.8 million people with warm water in a district heating system that will make use of waste heat at factories (primarily at a steelwork), combine it with alternative energy sources and the district heating system that engages several district heating operators, and make use of intelligent hardware and software to control and balance the integrated system to achieve a robust heat supply, energy efficiency, and reduced $\mathrm{CO}_{2}$ emissions. Though it is a multibillion-dollar project, its payback period is expected to be only three years, making it a nice illustration that BoP and sound business cases can be combined. This project has not come about quickly. Danfoss engaged in its first joint venture in Anshan in 2007, established a factory to produce district heating substations in 2008, and then started to make contact with heating suppliers and local politicians, working together with Chinese parts suppliers. During this period, Danfoss cooperated closely with the Anshan city government, Angang Steel, and the Qianfeng District Heating Company. Contract preparations went on from 2011 until 2013. A party secretary had to be engaged and a presidential visit to Denmark made before the contract could be signed, a process during which the energy-saving systems in Denmark could also be demonstrated and documented. Danfoss had to find a way to make the infrastructural ecosystem visible and bring the potential ecosystem of the Chinese field of stakeholders together to make the project imaginable. ${ }^{3}$

Apart from being a BoP supplier of cheap heating, the project has far-reaching consequences for environment and city life and reflects a maturation of many years of investment in control and monitoring technologies informed by CSR perspectives within Danfoss itself. Simultaneously, it is also becoming robust by activating a multiplicity of firms and institutions in Denmark that can work on parts and pieces of such integrated systems. When all such elements are brought together, they create the possibility for a very promising form of co-development between China and Denmark, in which numerous companies can be combined in similarly large-scale projects to encourage sustainable development in a joint process of continuous improvement at many nodes of a huge network.

Like most MNCs, Danish corporations were attracted by the low costs and the market potential in countries such as China. This was also the early motivation for Novo Nordisk, which produces and markets pharmaceuticals, primarily insulin for diabetes treatment. In 1962, Novo Nordisk opened a production

\footnotetext{
${ }^{3}$ For more on the Anshan Project, see http://www.lsta.lt/ lt/events/view/470.
} 
line in China. It set up a sales office in 1994 and moved production facilities to the Tianjin Economic Development Area (TEDA) to benefit from lowered taxes and improved infrastructures (Chitour, 2013). In this respect, Novo Nordisk behaved out of normal selfinterest, like most MNCs. But by simultaneously investing in local R\&D, applying its high global standards in monitoring quality, and deliberately trying to keep labor turnover low by offering good working conditions (by transforming toward team-based forms of work), it merged its business focus and CSR ambitions. Moreover, it created educational programs for pharmacists, awareness campaigns for patients and medical doctors, and programs for training patients. Its R\&D center enabled it to set up a set of strategic partnerships with various actors of the industry at different levels: policy makers, local manufacturers, healthcare providers, and patients. It earned the trust of the Chinese government by "delivering quality products and being involved in sponsoring national prevention campaigns," and by increasing "awareness of diabetes in rural China and other remote areas, which have little or no access" to healthcare professionals (Chitour, 2013, p. 39).

Novo Nordisk has thus adopted a holistic approach, focusing on physician training, patient education, strengthening the healthcare system, and creating public awareness of the dangers of diabetes, and it combines this focus with local production and R\&D (Chitour, 2013). By 2013, 55,000 doctors had participated in a series of seminars and conferences, and 280,000 patients have been educated since 1997 . Since Novo Nordisk gained a market share of $63 \%$ and achieved a position in relation to the Chinese government that prevents it from becoming an object of "the drug price slashing wave that hit many pharmaceutical companies following the Anhui Model reform" (Chitour, 2013, p. 43), one could see this approach as a way for the company to show great skill in constructing a market for itself. But a closer look reveals that the story is so full of shared interests among the company, the patients, the health care personnel, and the government that one cannot help seeing it as a very good example of the creation of codevelopment through shared value, something that was achieved through a mutual and gradual learning process by which different actors changed roles, habits, and even interests.

This admirable process and outcome becomes even more admirable if one studies how the company applied a similar approach in Bangladesh. Given that the national legacy and the institutional context were different, Novo Nordisk followed a different, more targeted route to helping an NGO that works with diabetes patients to teach patients to advocate for their own interests, educate doctors, subsidize medicine for low-income groups, and set up a logistical system for distributing medicine that would not jeopardize quality. ${ }^{4}$ By doing so it improved access to care, doctors' ability to diagnose and treat disease, and the logistical system's ability to serve, and created jobs in transportation services. It truly acted as an agency for a generative economy.

Recently Novo Nordisk engaged in a similar way in Brazil and Indonesia. The latter engagement has been studied by Verena Girschik (2016), who documented how Novo Nordisk connects foreign educators with the World Diabetes Foundation to empower a professional organization of doctors and the University of Indonesia to improve the regulatory capabilities of the government and improve the early diagnosis and treatment of diabetes patients. Girschik's account is an interesting study of how an MNC may be able to not only help establish an advanced organizational field with a complex set of actors, but also how this indirectly makes the company an agent of change for an entire institutional system. By periodically assessing the emerging system's success in terms of early detection of diabetes, precise diagnosis, and correct treatment of patients, Novo Nordisk is able to identify possible problems and advise patient and professional organizations, and through them health authorities, to improve the system. In addition to this, Novo Nordisk is highly aware of how the way it operates affects the rest of society. In its internal report on China, ${ }^{5}$ a very comprehensive register of effects is taken into consideration, including more than just the number of saved lives. The report includes metrics for patients, doctors, government spending, and $\mathrm{CO}_{2}$ emissions. Novo has a method for calculating its value creation that simultaneously includes financial, economic, social, and environmental concerns. Under the rubric of economic effects, Novo Nordisk has calculated that by 2010 , it directly employed 4,000 people, indirectly employed 7,000 through suppliers, and also employed another 4,000 through employee re-spending. The nature of its relationships to suppliers would be worth reviewing, but unfortunately we have not been able to identify such a study.

\footnotetext{
${ }^{4}$ See http://www.novonordisk.com/content/dam/Denmark/ $\mathrm{HQ} /$ Sustainability/documents/blueprint-changing-diabetesin-bangladesh-through-sustainable-partnerships.pdf.

${ }^{5}$ See http://www.novonordisk.com/content/dam/Denmark/ $\mathrm{HQ} /$ Sustainability/documents/Blueprint $\%$ 20for \%20change $\%$ 20-\%20China.pdf.
} 


\section{DISCUSSION}

As Kelly (2003, 2012) and Porter and Kramer (2006, 2011) have suggested, it is possible for corporations to play a generative role in creating shared value if they are not forced to optimize short-term shareholder value. Grundfos, Danfoss, and Novo Nordisk together with many other larger corporations in Denmark are all owned by foundations, often run by families of the founder. Form of ownership thus seems to be a core condition for engaging in this way with home and host economies. Yet despite the fact that the SMNCs mentioned in this article have been taken over by larger, foreign MNCs that are acting under the financial market of corporate governance, it has been possible to cultivate within these larger MNCs a pattern of development that in many ways resembles that of the larger Danish MNCs owned by foundations.

Whereas the mentioned projects by Grundfos, Danfoss, and Novo Nordisk have effects on a societal level, most Danish SMNCs engage in much narrower systems, such as those mentioned in relation to Unimerco and Radiometer. But in many ways, the logic of the relations of co-development takes on many of the same mechanisms. The focus is on a product, but the services delivered are ones that help customers transform their activities within a functional area or micro-strategic field. This happens when companies take part in close collaboration, engaging a multiplicity of different stakeholders within the customer company or institution and acting as suppliers of training and education-either directly or indirectly. The Danish firms construct a collaborative community (Heckscher \& Adler, 2006), so to speak, between the two involved organizations, a collaborative community that, by connecting the parties into micro-chains of enablers, might have much wider repercussions on the possibilities for developing still more advanced business models for both.

In the case of SMNCs it seems to be the way they have reformed their work organization that has provided them with such agility that they are able to respond to financial performance criteria while also being able to cultivate a business model that can engage in creating shared value. It is worth noticing that both the SMNCs within larger MNCs and the group of shared-value MNCs are filling out an economic space that has been created by the unfolding logic of the dominant capitalist process guided by the intellectual turn to neo-liberalism. As such the emerging forms of MNCs are complementary rather than in opposition to the dominant process. The big question, however, is whether the balance between the two may tip. The new emerging forms of SMNCs and shared-value MNCs have a generative potential that may improve the positioning of groupings, institutions, firms, and MNCs of emerging economies, and how that will in turn change the dominant process is an open question.

In our view the predisposition to engage in shared value creation is almost a habit that for firms and corporations has been rehearsed within such institutional environments as the Danish welfare state, with its emphasis on welfare services, environmental policies, and energy saving-a perspective that simultaneously penetrates the educational and vocational training system and equips professions with a mental frame and ethical norms. Thus, for Danish firms it is probably much easier to recruit highly skilled workers because they share such fundamental mental and ethical orientations.

However, as we saw, the welfare state plays a crucial role in enabling the mentioned reforms in work organization. As a proportion of GNP, public spending on social services in Nordic countries is higher than anywhere else (Kristensen \& Lilja, 2011, Chapter 1). In particular in Denmark, during the 1990s such services were combined in individualized action plans to help unemployed and marginal groups to move closer to the core labor market, making it possible for firms on a general scale to transform toward learning forms of organization. Through a combination of social insurance, further training, treatment of addiction problems, and access to childcare and eldercare each individual was "made ready" for the reformed labor market and was given a chance to take part in the new form of working life that emerged.

After the election in 2001 and even more since the financial crisis, with its emphasis on austerity, governments took a slightly different route; cuts in employment services, further training, and duration of unemployment periods have reduced the possibilities for unemployed and marginalized groups to upgrade their skills and overcome the barriers that follow from a highly demanding labor market. During the same period unions have become significantly weakened, while the state has become more reluctant to impose high costs on firms related to environmental and energy-saving concerns (see also Kristensen, 2015). Politics has become focused on reducing costs rather than on providing a capacitating supply of manpower and demand for prospective, innovative products and services.

The recent turn to and institutionalization of austerity in the European Union, including the Danish 
economy, risks undermining the new growth and development regime that emerged in the 1990s. Some of the institutional enablers are much less capacitating for firms and employees than they used to be. The question is whether the firms themselves have gained such a momentum and self-reflectiveness that they are able to generate compensating institutional enablers in their home economies. Lessons learned by involving themselves in generative processes in emerging economies might here become crucial.

\section{REFERENCES}

Aglietta, M. (1979). A theory of capitalist regulation: The US experience. London: New Left Books.

Andre, T. (2014). Corporate social responsibility boosts value creation at the base of the pyramid (Cahier de Recherche, 2014-11). Paris: Departement d'Economie, Ecole Polytechnique.

Bogason, P. (2001). Fragmenteret forvaltning: Demokrati og netværksstyring i decentraliseret lokalstyre. Århus, Denmark: Systime.

Boltanski, L., \& Chiapello, E. (2007). The new spirit of capitalism. London: Verso.

Chitour, H. L. (2013). The key drivers behind Novo Nordisk's growth in the diabetes market in China. European Journal of Interdisciplinary Studies, 5(2), 31-46.

Dalton, M. (1959). Men who manage. New York: Wiley.

Davis, G. F. (2009). Managed by the markets: How finance reshaped America. Oxford, UK: Oxford University Press.

Dörrenbächer, C., \& Geppert, M. (Eds.). (2011). Politics and power in the multinational corporation: The role of institutions, interests and identities. Cambridge, UK: Cambridge University Press.

Eriksson, T., Ibsen, R., \& Westergaard-Nielsen, N. (2006). Globalisering og det danske arbejdsmarked. Copenhagen: Jurist-og Økonomforbundets Forlag.

Fligstein, N., \& McAdam, D. (2012). A theory of fields. Oxford, UK: Oxford University Press.

Girschik, V. (2016). Realizing corporate responsibility: Positioning and framing in nascent institutional change (PhD Series 03.2016). Copenhagen: Copenhagen Business School.

Guillén, M. F. (2005). The rise of Spanish multinationals: European business in the global economy. Cambridge, UK: Cambridge University Press.

Guillén, M. F., \& García-Canal, E. (2010). The new multinational: Spanish firms in global context. New York: Cambridge University Press.
Guillén, M. F., \& García-Canal, E. (2013). Emerging markets rule: Growth strategies of the new global giants. New York: McGraw-Hill.

Hall, P. A., \& Soskice, D. (Eds.). (2001). Varieties of capitalism: The institutional foundations of comparative advantage. Oxford, UK: Oxford University Press.

Heckscher, C., \& Adler, P. S. (Eds.). (2006). The firm as a collaborative community: Reconstructing trust in the knowledge economy. Oxford, UK: Oxford University Press.

Helper, S., MacDuffie, J. P., \& Sabel, C. F. (2000). Pragmatic collaborations: Advancing knowledge while controlling opportunism. Industrial and Corporate Change, 10(3), 443-483.

Herrigel, G. (2010). Manufacturing possibilities. Oxford, UK: Oxford University Press.

Herrigel, G. (2014). Globalization and the German industrial production model. Unpublished manuscript, University of Chicago.

Herrigel, G., Wittke, V., \& Voskamp, U. (2013). The process of Chinese manufacturing upgrading: Transforming from unilateral to recursive mutual learning relations. Global Strategy Journal, 3, 109-125.

International District Energy Association. (2014). Danfoss wins GreenTec award 2014 for Chinese waste-heat recovery district heating solution. Westborough, MA: International District Energy Association. Available at http://www.districtenergy.org/blog/2014/05/12/ danfoss-wins-greentec-award-2014-for-chinese-wasteheat-recovery-district-heating-solution

Jackall, R. (1988). Moral mazes: The worlds of corporate managers. New York: Oxford University Press.

Jenkins, R. (2005). Globalization, corporate social responsibility and poverty. International Affairs, 81(3), 525-540.

Keating, C., \& Schmidt, T. (2008). Opportunities and challenges for multinational corporations at the base of the pyramid. In P. Kandacher \& M. Halme (Eds.), Sustainability challenges and solutions at the base of the pyramid: Business, technology and the poor (pp. 387-410). Sheffield, UK: Greenleaf Publishing Limited.

Kelly, M. (2003). The divine right of capital: Dethroning the corporate aristocracy. Oakland, CA: Berrett-Koehler Publishers.

Kelly, M. (2012). Owning our future: The emerging ownership revolution. Journey to a generative economy. Oakland, CA: Berrett-Koehler Publishers.

Kirkegaard, J. K. (2015). Ambiguous winds of change-or fighting against windmills in Chinese wind power $(\mathrm{PhD}$ Series 05.2015). Copenhagen: Copenhagen Business School. 
Kristensen, P. H. (2013). The distinctiveness of Nordic welfare states in the transformation to the projective city and the new spirits of capitalism. In P. Du Gay \& G. Morgan (Eds.), New spirits of capitalism? Crises, justifications, and dynamics (Chapter 9). Oxford, UK: Oxford University Press.

Kristensen, P. H. (2015). Fighting the financial crisis: The social construction and deconstruction of the financial crisis in Denmark. In G. Morgan, P. Hirsch, \& S. Quack (Eds.), Elites on trial: Research in the sociology of organizations (Vol. 43, pp. 371-398). Bingley, UK: Emerald Books.

Kristensen, P. H., \& Lilja, K. (Eds.). (2011). Nordic capitalism and globalization: New forms of economic organization and welfare institutions. Oxford, UK: Oxford University Press.

Kristensen, P. H., \& Lotz, M. (2011). Taking teams seriously in the co-creation of firms and economic agency. Organization Studies, 32(11), 1465-1484.

Kristensen, P. H., \& Morgan, G. (2012). From institutional change to experimentalist institutions. Industrial Relations, 51(S1), 413-437.

Kristensen, P. H., Rocha, R. S., \& Lotz, M. (2011). Denmark: Tailoring flexicurity for changing roles in global games. In P. H. Kristensen \& K. Lilja (Eds.), Nordic capitalism and globalization: New forms of economic organization and welfare institutions (Chapter 3). Oxford, UK: Oxford University Press.

Kristensen, P. H., \& Zeitlin, J. (2004). Local players in global games: The strategic constitution of a multinational corporation. Oxford, UK: Oxford University Press.

Lazonick, W., \& O’Sullivan, M. (2000). Maximizing shareholder value: A new ideology of corporate governance. Economy and Society, 29(1), 13-35.

Locke, R. M. (2013). The promise and limits of private power: Promoting labor standards in a global economy. New York: Cambridge University Press.

Lorenz, E., \& Valeyre, A. (2003, June). Organizational change in Europe: National models or the diffusion of a new "one best way"? Paper presented at the 15th Annual Meeting on Socio-Economics, LEST, Aix en Provence.

Lotz, M. (2009). The business of co-creation-and the cocreation of business (PhD Series 15-2009). Copenhagen: Copenhagen Business School.

Madsen, P. K. (2006). How can it possibly fly? The paradox of a dynamic labour market in a Scandinavian welfare state. In J. L. Campbell, J. A. Hall, \& O. K. Pedersen (Eds.), National identity and the varieties of capitalism: The Danish experience (pp. 323-355). Montreal: McGill-Queen's University Press.

Matten, D., \& Moon, J. (2008). “Implicit” or “explicit” CSR: A conceptual framework for understanding CSR in Europe. Academy of Management Review, 33(2), 404-424.
Maurice, M., Sellier, F., \& Silvestre, J.-J. (1986). The social foundation of industrial power. Cambridge, MA: MIT Press.

Mayer, C. (2013). Firm commitment. Why the corporation is failing us and how to restore trust in it. Oxford, UK: Oxford University Press.

Mayer, F., \& Gereffi, G. (2010). Regulation and economic globalization: Prospects and limits of private governance. Business and Politics, 12(3), 1-25.

Morgan, G. (1997). Financial security, welfare regimes, and the governance of work systems. In R. Whitley \& P. H. Kristensen (Eds.), Governance at work: The social regulation of economic relations (pp. 104-122). Oxford, UK: Oxford University Press.

Morgan, G., \& Kristensen, P. H. (2014). The comparative analysis of capitalism and the study of organizations. In P. Adler, P. Du Gay, G. Morgan, \& M. Reed (Eds.), The Oxford handbook of sociology, social theory and organization studies (Chapter 10). Oxford, UK: Oxford University Press.

Mueller, F. (1996). National stakeholders in the global contest for corporate investment. The Journal of Industrial Relations, 2, 345-368.

Mueller, F., \& Purcell, J. (1992). The Europeanization of manufacturing and the decentralization of bargaining: Multinational management strategies in the European automobile industry. International Journal of Human Resource Management, 3, 15-31.

Nielsen, K. (Ed.). (2013). Danmarks eksportkanon. Copenhagen: Trade Council of the Foreign Ministry and Mandag Morgen.

Porter, M., \& Kramer, M. K. (2006). Strategy and society. The link between competitive advantage and corporate social responsibility. Harvard Business Review, (December), 1-13.

Porter, M. E., \& Kramer, M. K. (2011). Creating shared value. Harvard Business Review, (January-February), 3-17.

Prahalad, C. K. (2004). The fortune at the bottom of the pyramid. Philadelphia: Wharton School Publishing.

Sabel, C. F. (1994). Learning by monitoring: The institutions of economic development. In N. J. Smelser \& R. Swedberg (Eds.), The handbook of economic sociology (pp. 137-165). Princeton, NJ: Princeton University Press.

Sabel, C. F. (2006). A real-time revolution in routines. In C. Heckscher \& P. S. Adler (Eds.), The firm as a collaborative community: Reconstructing trust in the knowledge economy. Oxford, UK: Oxford University Press.

Selznick, P. (1957). Leadership in administration: A sociological interpretation. Berkeley, CA: University of California Press. 
Streeck, W. (2009). Re-forming capitalism: Institutional change in the German political economy. Oxford, UK: Oxford University Press.

Torfing, J. (2003). Det stille sporskifte $i$ velfærdsstaten. Århus, Denmark: Århus Universitetsforlag.

Whitley, R. (1999). Divergent capitalisms: The social structuring and change of business systems. Oxford, UK: Oxford University Press.
Peer Hull Kristensen (phkr.ioa@cbs.dk) is a professor in the sociology of firms and organization at the Copenhagen Business School. His research focuses on the changing relations among firms, multinationals, work organizations, and institutions. His most recent book, with Kari Lilja, is Nordic Capitalism and Globalization: New Forms of ECOnomic Organization and Welfare Institutions (Oxford University Press, 2011). 
Copyright of Academy of Management Perspectives is the property of Academy of Management and its content may not be copied or emailed to multiple sites or posted to a listserv without the copyright holder's express written permission. However, users may print, download, or email articles for individual use. 